\title{
The role of fimbriae and flagella in the adherence of avian strains of Escherichia coli 078:K80 to tissue culture cells and tracheal and gut explants
}

\author{
R. M. LA RAGIONE, W. A. COOLEY and M. J. WOODWARD
}

Bacteriology Department, Veterinary Laboratories Agency (Weybridge), New Haw, Addlestone, Surrey KT15 $3 N B$

\begin{abstract}
To investigate the role of fimbriae and flagella in the pathogenesis of avian colibacillosis, isogenic insertionally inactivated mutant strains of Escherichia coli O78:K80 strain EC34195 defective in the elaboration of type-1 and curli fimbriae and flagella were constructed by allelic exchange. Single and multiple non-fimbriate and non-flagellate mutant strains were compared to the wild-type in vitro in adherence assays with a HEp-2 cell line, a mucus-secreting cell line HT2916E, a non-mucus-secreting cell line HT2919A, tracheal explant and proximal gut explant. Mutant strains defective in the elaboration of type-1 fimbriae were significantly less adherent - in the order of $90 \%$ reduction - than the wild-type strain in all assays. Mutant strains defective in the elaboration of flagella were generally as adherent as the wild-type strain except when assayed with the mucus-secreting cell line HT2916E, for which a significant reduction of adherence - of the order of $90 \%$ - compared with the wild-type strain was observed. Mutant strains defective for the elaboration of curli fimbriae adhered as well as the wild-type strain in all assays, except when assayed in tests with gut explant tissue for which a significant reduction of adherence - of the order of $80 \%$ - compared with the wild-type strain was observed. Adherence to explants was to epithelial, not serous, surfaces and was 10-fold greater to tracheal than to gut explants. Together, these data support the hypothesis that type-1 fimbriae are significant factors in adherence, aided by flagella for penetration of mucus and curli fimbriae for adherence to the gut.
\end{abstract}

\section{Introduction}

Escherichia coli is an important cause of disease in mammals, birds and reptiles [1]. In domestic poultry, avian colibacillosis is frequently associated with $E$. coli strains of serotypes O78:K80, O1:K1 and O2:K1 [2]. Infections commonly occur via the respiratory tract, often after a primary bacterial or viral infection or as a result of poor husbandry practices. The disease generally affects broilers between 3 and 10 weeks of age and is associated with high morbidity and mortality. Carcass condemnation at slaughter is common [3]. The most severe manifestation of avian colibacillosis is septicaemia which is characterised by pericarditis, perihepatitis, air sacculitis and salpingitis [4-7].

Received 15 June 1999; accepted 7 Sept. 1999.

Corresponding author: Professor M. J. Woodward (e-mail: mwoodward.cvl.wood@gtnet.gov.uk).
Adherence is a necessary prerequisite for bacterial colonisation and pathogenesis. To withstand the mechanical cleansing and bulk flow associated with intestinal mucosal surfaces, bacteria bind specifically to epithelial and mucosal surfaces [8], often by proteinaceous surface appendages called fimbriae. Avian isolates of E. coli commonly express type-1, $\mathrm{P}$ and curli fimbriae and commonly possess flagella which confer motility [9]. Type-1 fimbriae confer mannose-sensitive haemagglutination, whereas $\mathrm{P}$ fimbriae confer mannose-resistant haemagglutination. Both type-1 and $\mathrm{P}$ fimbriae have been cited as important factors for adherence to epithelial cell surfaces in vitro and in vivo [3,10-14] and type-1 fimbriae are also thought to be important in the initial stages of infections of poultry by $E$. coli strains of serogroups $\mathrm{O} 1$ and $\mathrm{O} 2$ [8, 11, 15-17]. The role of curli fimbriae in poultry infection by $E$. coli remains unstudied, although it has been demonstrated that in vitro they mediate binding to fibronectin, laminin, plasminogen, plasminogen activator proteins and type-1 collagen [18-22]. The role of flagella in the pathogenesis of 
avian colibacillosis is unclear, because isolates are often non-flagellate.

Avian strains of $E$. coli adhere to tracheal sections and epithelial cell lines [7, 10, 11, 15, 23, 24]. Other tissueculture and organ-explant approaches have been used to study the initial events of colonisation of different pathotypes of E. coli in vitro [25-29]. Recent studies of avian colibacillosis have focused on the role of individual kinds of surface antigens $[3,7,11]$. By contrast, the aim of the present study was to investigate the combined role of fimbriae and flagella in pathogenesis. As a first step, a reverse genetics approach was used to produce a library of nonfimbriate and non-flagellate single and multiple isogenic mutant strains of a clinical isolate of an avian strain of E. coli $\mathrm{O} 78: \mathrm{K} 70$. In this paper the construction of the library and its use in various tissue-culture and organ-explant adherence assays are described.

\section{Materials and methods}

\section{Bacterial isolates and media}

Wild-type strains of $E$. coli O78:K80 were obtained from the E. coli Reference Laboratory, VLA, Weybridge (Table 1). Strain EC34195 was used in all mutagenesis studies. Bacterial cultures were maintained on Dorset's egg slopes at $20^{\circ} \mathrm{C}$ and stored at $-80^{\circ} \mathrm{C}$ in heart infusion broth (HIB) supplemented with glycerol $30 \% \mathrm{v} / \mathrm{v}$. Working cultures were maintained at $4^{\circ} \mathrm{C}$ on sheep blood (5\%) agar, supplemented with antibiotics as appropriate. Luria Bertani (LB) Agar (Oxoid), supplemented with Xgal (Promega) $25 \mathrm{mg} / \mathrm{ml}$ and ampicillin (Penbrithin, Beecham) $100 \mu \mathrm{g} / \mathrm{ml}$, was used in all cloning procedures. Minimal medium was M9 salts medium supplemented with glucose $0.2 \% \mathrm{w} / \mathrm{v}$ and $10 \mathrm{~mm}$ magnesium sulphate. Bacteria for tissueculture adhesion and invasion assays were cultured statically in HIB at $37^{\circ} \mathrm{C}$ for $48 \mathrm{~h}$. They were prepared for adhesion by centrifugation at $4000 \mathrm{rpm}$ for $10 \mathrm{~min}$ at ambient temperature and resuspended in phosphatebuffered saline (PBS) to an optical density $(540 \mathrm{~nm})$ of 1.2 absorbance units. Bacteria for tissue-explant adhesion assays were cultured as for tissue-culture assays and were resuspended in PBS to an optical density $(550 \mathrm{~nm})$ of 0.6 absorbance units. In some experiments, bacteria were cultured aerobically in Colonisation Factor Antigen (CFA) Broth (Oxoid) at $25^{\circ} \mathrm{C}$ for $72 \mathrm{~h}$.

\section{Phenotypic analysis of E. coli isolates}

Procedures for mannose-sensitive and -resistant haemagglutination, motility, agglutination reactions, antibiotic resistance, fibronectin and Congo red binding, curli fimbriae ELISA and transmission and scanning electron microscopy were as described previously [32, 33, 36-38].

\section{Genetic methods}

Genetic methods, including plasmid and chromosomal DNA extraction and purification, restriction endonuclease digestion, agarose gel electrophoresis, ligation, preparation of electro-competent bacterial cells,

Table 1. Plasmids and bacteria used

\begin{tabular}{|c|c|c|}
\hline Plasmids and strains & Comments & Source \\
\hline pBLUESCRIPT & Cloning vector & Commercially available (Stratagene) \\
\hline pCRSRIPT & Direct PCR cloning vector & Commercially available (Stratagene) \\
\hline pBSL30 & Source of $\operatorname{str}^{r}$ & {$[30]$} \\
\hline \multirow[t]{3}{*}{ pBSL141 } & Source of gen ${ }^{r}$ & {$[30]$} \\
\hline & Source of $\mathrm{cam}^{\mathrm{r}}$ & Commercially available (Stratagene) \\
\hline & Source of $\mathrm{kan}^{\mathrm{r}}$ & Commercially available (Pharmacia) \\
\hline pJP5603 & $\operatorname{kan}^{\mathrm{r}}$ suicide vector & {$[31]$} \\
\hline pERFORM K & pJP5603 with modified MCS & {$[32,33]$} \\
\hline pERFORM C & pJP5603 with modified MCS and $\operatorname{kan}^{\mathrm{r}}$ replaced by $\mathrm{cam}^{\mathrm{r}}$ & {$[32,33]$} \\
\hline pERFORM G & pERFORM C with cam ${ }^{\mathrm{r}}$ replaced by gen ${ }^{\mathrm{r}}$ & This study \\
\hline E. coli JM109 $\lambda$ pir & $\begin{array}{l}\text { Cloning strain. Genotype: } 14^{-}\left(\mathrm{mcrA}^{-}\right) \text {recA } 1 \text { end A1 gyrA96thi } 1 \\
\text { hsd R17 }\left(\mathrm{r}_{\mathrm{k}}-\mathrm{m}_{\mathrm{k}}^{+}\right) \text {supE44 relA1 } \Delta \text { (lac-proAB) }\left[\mathrm{F}^{\prime} \operatorname{traD} 36 \text { proAB } \operatorname{lac}^{\mathrm{q}} \mathrm{z} \Delta \mathrm{M} 15\right] \\
\lambda \text { pir }\end{array}$ & {$[31]$} \\
\hline E. coli S-17 pir & Mobilising strain. Genotype: pro res- $\bmod ^{+} \mathrm{RP} 42^{-} \mathrm{Tc}:: \mathrm{Mu}^{-} \mathrm{Km}:: \operatorname{Tn} 7 \lambda$ pir & {$[34]$} \\
\hline EC43297 & Human urinary tract isolate & This study \\
\hline EC54597 & Wild-type avian $E$. coli $\mathrm{O} 78: \mathrm{K} 80$ strain & VLA Weybridge \\
\hline EC5197 & Wild-type avian E. coli $\mathrm{O} 78: \mathrm{K} 80$ strain & VLA Weybridge \\
\hline EC24197 & Wild-type avian $E$. coli $\mathrm{O} 78: \mathrm{K} 80$ strain & VLA Weybridge \\
\hline EC24297 & Wild-type avian E. coli $\mathrm{O} 78: \mathrm{K} 80$ strain & VLA Weybridge \\
\hline EC24397 & Wild-type avian $E$. coli $\mathrm{O} 78: \mathrm{K} 80$ strain & VLA Weybridge \\
\hline EC39597 & Wild-type avian $E$. coli $078: \mathrm{K} 80$ strain & VLA Weybridge \\
\hline EC43197 & Wild-type avian $E$. coli $\mathrm{O} 78: \mathrm{K} 80$ strain & VLA Weybridge \\
\hline EC47897 & Wild-type avian $E$. coli $\mathrm{O} 78: \mathrm{K} 80$ strain & VLA Weybridge \\
\hline EC30896 & Wild-type avian $E$. coli $\mathrm{O} 78: \mathrm{K} 80$ strain & VLA Weybridge \\
\hline EC26296 & Wild-type avian $E$. coli $\mathrm{O} 78: \mathrm{K} 80$ strain & VLA Weybridge \\
\hline EC34195 & Wild-type avian $E$. coli $\mathrm{O} 78: \mathrm{K} 80$ strain & {$[35]$} \\
\hline EC2597 & Wild-type avian $E$. coli $\mathrm{O} 78: \mathrm{K} 80$ strain & VLA Weybridge \\
\hline EC5497 & Wild-type avian $E$. coli $\mathrm{O} 78: \mathrm{K} 80$ strain & VLA Weybridge \\
\hline
\end{tabular}


electroporation, lysis of bacterial colonies for colony dot-blot hybridisation, Southern hybridisation and autoradiography were as described previously [39]. Probes for radiolabelled probing were either purified PCR products or entire plasmids.

\section{PCR}

Primers were designed to amplify fim $C, f i C$, pap $A$ and $\operatorname{csg} A$ (Table 2). PCR reactions were set up in 50- $\mu 1$ volumes containing water, Thermo DNA polymerase reaction buffer (Promega), $200 \mu \mathrm{M}$ dNTPs (Pharmacia), $1.5 \mathrm{mM} \mathrm{MgCl}_{2}$, thermostable Taq polymerase (Promega) 2.5 units, 10 pmols of each primer and total genomic DNA $1 \mathrm{ng}$ from E. coli O78:K80 strain EC34195. Reactions were overlaid with mineral oil (Promega) $50 \mu \mathrm{l}$ and cycling was carried out in a thermo-cycler (Biometra) with the following programme: initial denaturation at $95^{\circ} \mathrm{C}$ for $5 \mathrm{~min}$ followed by 30 cycles of denaturing for $2 \mathrm{~min}$ at $95^{\circ} \mathrm{C}$, annealing at $56^{\circ} \mathrm{C}$ for $1.5 \mathrm{~min}$, extension at $72^{\circ} \mathrm{C}$ for $2 \mathrm{~min}$, and thereafter by a final extension at $72^{\circ} \mathrm{C}$ for $10 \mathrm{~min}$. PCR products were stored at $4^{\circ} \mathrm{C}$ until required.

\section{Nucleotide sequencing and analysis}

The BigDye terminator cycle sequencing kit (Perkin Elmer) was used in all reactions. Individual reaction mixtures $20 \mu \mathrm{l}$ contained plasmid DNA $400 \mathrm{ng}$ or PCR amplified DNA $200 \mathrm{ng}$, primer $3.2 \mathrm{pmol}$ and Ready Reaction Mix (Perkin Elmer) $8 \mu \mathrm{l}$ in Eppendorf tubes. Reactions were overlaid with mineral oil, extensions were performed in a thermo-cycler (Perkin-Elmer) and prepared for analysis on a 377 automated DNA sequencer following the manufacturer's instructions (Applied Biosystems) Trace data were analysed and assembled with the use of DNA Star software (DNAStar).

\section{Cloning and insertional inactivation of fimbrial and flagellar genes}

Mutagenesis was carried out by allelic exchange $[32,33,36]$ and the preparative stages for each mutational event are listed in Table 3. In brief, DNA fragments encoding the $f i m C, \operatorname{csg} A$ and $f i C$ genes, each flanked by immediately adjacent sequences, were amplified by PCR with total genomic DNA extracted from E. coli strain EC34195 of O78:K80 as a template. Amplicons were cloned into pCR-Script plasmid vector (Stratagene) with E. coli K12 strain DH5a (Gibco $\mathrm{BRL}$ ) as host. Plasmids were mapped by restriction endonuclease digestion and DNA nucleotide sequences were confirmed as described above. Antibiotic resistance cassettes were cloned into appropriate unique restriction sites in the centre of each gene. Insertionally inactivated genes were subcloned into appropriate pERFORM plasmid vectors [33] and electroporated into the permissive auxotrophic host $E$. coli $\mathrm{K} 12$ strain S-17 $\lambda$ pir with selection for both the antibiotic resistance marker encoded by the resistance cassette and the antibiotic resistance marker conferred by the suicide vector antibiotic gene.

\section{Conjugation}

The pERFORM vectors harbouring antibiotic resistance-marked, insertionally inactivated genes were transferred by conjugation from the permissive host E. coli $\mathrm{K} 12$ strain $\mathrm{S}-17 \lambda$ pir into the non-permissive E. coli O78:K80 recipient strain EC34195 by filter mating as described before [33] with selection made for the antibiotic resistance marker conferred by the cassette used to inactivate the targeted gene.

\section{Selection of mutant strains}

Individual colonies from conjugation selective plates were streaked on to fresh glucose minimal medium supplemented with appropriate antibiotic (i.e., the antibiotic to which resistance was encoded by the insert of the inactivated gene) and cultured overnight at $37^{\circ} \mathrm{C}$. Individual colonies were tested for loss of the antibiotic resistance conferred by the suicide vector. Putative double cross-over mutant strains were streaked to single colonies three times before confirmatory genotypic and phenotypic testing. Mutant strains are listed in Table 4.

\section{Pathogenicity of strain EC34195 in 1-day-old chicks}

Eighteen 1-day-old SPF white Leghorn chicks were separated randomly into two groups of nine birds each and housed in separate isolators. All birds in one group

Table 2. The sequences and sources of primers used in mutagenesis studies

\begin{tabular}{|c|c|c|c|}
\hline $\begin{array}{l}\text { Primer } \\
\text { identity }\end{array}$ & Sequence $5^{\prime}-3^{\prime}$ & $\begin{array}{l}\text { Position } \\
\text { (bp) }\end{array}$ & $\begin{array}{c}\text { Accession } \\
\text { number }\end{array}$ \\
\hline fim $\mathrm{C} 1$ & TTTCAGCTGAATGCGGATGCGACCTTCAAG & $3501-3521$ & $\mathrm{Z} 37500$ \\
\hline fim $\mathrm{C} 2$ & AAACAGCTGCATCACGCGTTGCCATATAAC & $5248-5227$ & Z37500 \\
\hline $\operatorname{csgA} 1$ & TTTAGGCCTTATTGATCGCACACCTGACAG & $2498-2518$ & X90754 \\
\hline $\operatorname{csgA} 2$ & AAAAGGCCTCCAAGGGTTGTGTTATCCATA & $4665-4645$ & X90754 \\
\hline fliC 1 & 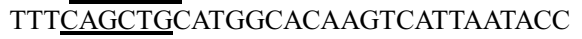 & $101-122$ & Z36877 \\
\hline fliC 2 & AAACAGCTGGATAAGCGCAGCGCATA & $1861-1846$ & Z36877 \\
\hline papA 1 & AACTATTCCACAGGGGCA & $1834-1851$ & X61239 \\
\hline papA 2 & CAGGTTGAAATTCGCAAC & $2291-2308$ & X61239 \\
\hline
\end{tabular}

Underlined sequences denote engineered restriction enzyme sites ( $f i m C, P v u \mathrm{II} ; \operatorname{csg} A$, StuI; $f i C$, Pvu II). 
were dosed by intra-gastric intubation with EC34195 bacteria $\left(0.1 \mathrm{ml}\right.$ containing $\left.1 \times 10^{9} \mathrm{cfu}\right)$ and all birds in the other group received a similar dose subcutaneously. Birds were given standard rations and water ad libitum. Three birds were randomly selected from each group and killed by cervical dislocation at 24, 48 and $168 \mathrm{~h}$ for detailed examination at necropsy. Histological examination of tissues was done after staining with haematoxylin and eosin and Giemsa [40].

\section{Tissue-culture adherence and invasion assays}

The mucus-secreting cell line HT2916E [41] was sown $2 \times 10^{5}$ cells in 24-well plates in Dulbecco's modified Eagle's medium (Sigma) supplemented with fetal calf serum $10 \%$, non-essential amino acids $(\times 100) 1 \%$, $2 \mathrm{mM}$ L-glutamine and gentamicin (Sigma), $50 \mu \mathrm{g} / \mathrm{ml}$. Monolayers were incubated for 5 days and were fed on alternate days. By day 5, a confluent mucus layer was detectable on the surface of HT2916E cells. Before use, monolayers were washed twice with Hanks's balanced salts solution (HBSS) to remove cell debris and residual gentamicin. The bacterial inoculum was added $\left(1 \times 10^{8} \mathrm{cfu} / \mathrm{ml}\right)$ in incomplete Dulbecco's medium (without antibiotics or fetal calf serum) and added in $1-\mathrm{ml}$ volumes to each well. Monolayers were then incubated at $37^{\circ} \mathrm{C}$ supplemented with $\mathrm{CO}_{2} 5 \%$ for $2 \mathrm{~h}$. The inoculum was removed and the monolayer was washed six times with $1 \mathrm{ml}$ of HBSS to remove nonadherent bacteria. The monolayer was then disrupted for 10 min with a solution of Triton 100 (Sigma) 1\% and a 12-mm magnetic stirrer. After disruption for $10 \mathrm{~min}, 10$-fold serial dilutions were plated on to LB agar and incubated overnight at $37^{\circ} \mathrm{C}$ to determine the count $(\mathrm{cfu} / \mathrm{ml})$. A non-mucus-secreting cell line, HT2919A, was used as a control [41, 42]. HEp-2 cells were prepared as above except that they were grown for $48 \mathrm{~h}$ in Eagle's Minimal Essential Medium (EMEM; Sigma). All assays were repeated at least twice on at least two separate occasions.

For invasion assays, bacteria were allowed to adhere to HEp-2 or HT2916E cells for $2 \mathrm{~h}$, at which time monolayers were washed three times with HBSS before adding EMEM containing gentamicin $100 \mu \mathrm{g} / \mathrm{ml}$. Plates were incubated at $37^{\circ} \mathrm{C}$ in $\mathrm{CO}_{2} 5 \%$ for $2 \mathrm{~h}$ and washed three times with HBSS. Monolayers were then disrupted with Triton 100 solution $1 \%$ and the number of cfu was determined [37].

\section{Tracheal and proximal gut explant adhesion assay}

One-day-old SPF white Leghorn chicks were killed by cervical dislocation. Lengths $(c .2 \mathrm{~cm})$ of the trachea and proximal gut (duodenal loop) were removed aseptically to sterile Krebs'-Ringer's solution. Fatty tissue and mesentery were removed from the gut sections and tissues were cut to expose the villiated surfaces $\left(c .1 \mathrm{~cm}^{2}\right)$ for use in adherence assays as described above. Sections were gently washed twice in 
Table 4. Library of fimbrial and flagellar mutant strains of E. coli O78:K80 strain EC34195

\begin{tabular}{|c|c|c|c|}
\hline $\begin{array}{l}\text { Strain } \\
\text { no. }\end{array}$ & Genotype & $\begin{array}{l}\text { Antibiotic resistance } \\
(\mu \mathrm{g} / \mathrm{ml})\end{array}$ & Phenotype \\
\hline RML1 & $f i m C:: \mathrm{kan}^{\mathrm{r}}$ & Kanamycin $(25)$ & $\mathrm{MSHA}^{-}$ \\
\hline RML2 & $\operatorname{csg} A:: \operatorname{cam}^{\mathrm{r}}$ & Chloramphenicol (10) & Lacy $^{-}$, curli ELISA ${ }^{-}$, Congo red $^{-}$and fibronectin ${ }^{-}$ \\
\hline RML3 & $\begin{array}{l}\text { fim } C:: \operatorname{kan}^{\mathrm{r}} \\
\operatorname{csg} A:: \operatorname{cam}^{\mathrm{r}}\end{array}$ & $\begin{array}{l}\text { Kanamycin (25) } \\
\text { Chloramphenicol (10) }\end{array}$ & 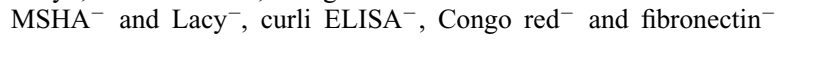 \\
\hline RML6 & $f i C:: \operatorname{str}^{\mathrm{r}}$ & Streptomycin $(25)$ & Non-motile \\
\hline RML7 & $\begin{array}{l}\text { fimC }:: \operatorname{kan}^{\mathrm{r}} \\
f i l C:: \mathrm{str}^{\mathrm{r}}\end{array}$ & $\begin{array}{l}\text { Kanamycin (25) } \\
\text { Streptomycin (25) }\end{array}$ & $\mathrm{MSHA}^{-}$and non-motile \\
\hline RML8 & $\begin{array}{l}\operatorname{csg} A:: \operatorname{cam}^{\mathrm{r}} \\
f l i C:: \operatorname{str}^{\mathrm{r}}\end{array}$ & $\begin{array}{l}\text { Chloramphenicol (10) } \\
\text { Streptomycin }(25)\end{array}$ & Lacy $^{-}$, curli ELISA ${ }^{-}$, Congo red ${ }^{-}$, fibronectin ${ }^{-}$and non-motile \\
\hline RML9 & 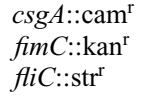 & $\begin{array}{l}\text { Kanamycin }(25) \\
\text { Chloramphenicol (10) } \\
\text { Streptomycin }(25)\end{array}$ & Lacy $^{-}$, curli ELISA ${ }^{-}$, Congo red ${ }^{-}$fibronectin ${ }^{-} \mathrm{MSHA}^{-}$and non-motile \\
\hline
\end{tabular}

pre-warmed Krebs'-Ringer's solution and immersed individually in fresh sterile Krebs'-Ringer's solution in a $50-\mathrm{ml}$ Falcon tube $(\mathrm{BDH})$ to which $1 \mathrm{ml}$ of the bacterial inoculum $\left(1 \times 10^{8} \mathrm{cfu} / \mathrm{ml}\right)$ was added. Incubation was at $37^{\circ} \mathrm{C}$ with orbital rotation at $225 \mathrm{rpm}$ for up to $180 \mathrm{~min}$. At timed intervals, sections were rinsed three times in fresh sterile pre-warmed Krebs'Ringer's solution to remove all non-adherent bacteria and then homogenised. Serial dilutions of homogenates were plated in triplicate on to LB agar plates which were incubated at $37^{\circ} \mathrm{C}$ overnight and bacterial counts were determined. All assays were repeated at least twice on at least two separate occasions.

\section{Statistical analyses}

Bacterial counts were converted to $\log _{10}$ values for statistical analysis. Repeated measures analyses of variance were done with the Statistica or Genstat 5 software packages. The means, SEMs and significances (p) of strain differences were calculated.

\section{Results}

Characterisation of avian isolates of E. coli O78:K80

To select one isolate of E. coli O78:K80 for study, specific criteria were established, namely that the isolate should express relevant surface appendages, be sensitive to antibiotics and be pathogenic. Thirteen isolates of E. coli $\mathrm{O} 78: \mathrm{K} 80$ were tested for haemagglutination (type-1 and P fimbriae), motility (flagella), colony morphology, Congo red and fibronectin binding (curli fimbriae) and observed by transmission electron microscopy for the presence of these and other surface appendages. None of the isolates elaborated mannoseresistant haemagglutination, but considerable variability in the elaboration of flagella and type- 1 and curli fimbriae was noted (Table 5). Each isolate was tested against a panel of 16 antibiotics (VLA, Weybridge Enteric Bacteria Testing Section) and three antibioticsensitive isolates - EC30896, EC5197 and EC34195 which possessed type-1 fimbriae, curli fimbriae and flagella were selected for further study. Their $f i C$, fimC and $\operatorname{csg} A$ genes were amplified successfully by PCR and these amplicons were cloned, mapped by restriction endonuclease digestion and confirmed by DNA sequence analysis. PCR with pap primers failed to generate an amplicon for any of the isolates tested, whereas amplicons were derived successfully by PCR from a control strain (EC43297) of E. coli isolated from a patient with urinary tract infection.

Strain EC34195 was tested in the day-old SPF chick pathogenicity model. Birds were inoculated subcutaneously or by the oral route and selected at random from both dosage groups for analysis at necropsy 24 ,

Table 5. Phenotypic characters of E. coli O78:K80 isolates

\begin{tabular}{|c|c|c|c|c|c|c|c|c|c|}
\hline $\begin{array}{l}\text { Strain } \\
\text { no. }\end{array}$ & $\begin{array}{l}\text { Elaboration } \\
\text { of curli } \\
\text { fimbriae }\end{array}$ & $\begin{array}{c}\text { Colony } \\
\text { morphology }\end{array}$ & $\begin{array}{l}\text { Congo } \\
\text { red } \\
\text { binding }\end{array}$ & $\begin{array}{l}\text { Fibronectin } \\
\text { binding }\end{array}$ & $\begin{array}{l}\text { Elaboration } \\
\text { of type-1 } \\
\text { fimbriae }\end{array}$ & $\begin{array}{l}\text { Haemagglutination of } \\
\text { chicken or guinea- } \\
\text { pig erythrocytes }\end{array}$ & $\begin{array}{c}\text { Elaboration } \\
\text { of } \\
\text { flagella }\end{array}$ & Motility & $\begin{array}{c}\text { Flagellar } \\
\text { antigen }\end{array}$ \\
\hline EC54597 & - & S & - & \pm & + & + & + & + & 51 \\
\hline EC5197 & + & $\mathrm{L}$ & + & + & + & + & + & + & 9 \\
\hline EC24197 & + & $\mathrm{L}$ & + & + & + & + & - & - & - \\
\hline EC24297 & + & $\mathrm{L}$ & + & + & + & + & - & - & - \\
\hline EC24397 & + & $\mathrm{L}$ & + & + & + & + & - & - & - \\
\hline EC39597 & + & $\mathrm{S} / \mathrm{L}$ & + & + & + & + & + & + & 51 \\
\hline EC43197 & + & $\mathrm{L}$ & + & + & - & - & + & - & 51 \\
\hline EC47897 & + & $\mathrm{S} / \mathrm{L}$ & + & + & + & + & + & + & 9 \\
\hline EC30896 & + & $\mathrm{S} / \mathrm{L}$ & + & + & + & + & + & + & 9 \\
\hline EC26296 & + & $\mathrm{S} / \mathrm{L}$ & + & + & - & - & - & - & - \\
\hline EC34195 & + & $\mathrm{L}$ & + & + & + & + & + & + & 9 \\
\hline EC2597 & - & S & - & \pm & - & - & + & + & 11 \\
\hline EC5497 & - & $\mathrm{S}$ & - & \pm & - & - & + & + & 11 \\
\hline
\end{tabular}

L, Lacy; S, smooth colonies; \pm , binding to fibronectin at low level. 
48 and $168 \mathrm{~h}$ after infection. Histological examination of tissues from diseased birds showed generalised congestion of the heart, with suppurative pericarditis and epicarditis. Examination of liver tissues revealed congestion with mild multifocal cellular infiltration and focal hepatocyte vacuolation.

Construction of isogenic mutant strains of E. coli O78:K80 EC34195

Single and multiple mutant strains were constructed in strain EC34195 as described above. Southern hybridisation analysis of each mutant strain and of the wildtype progenitor strain EC34195 were compared. Hybridisation with the native target gene PCR product showed an increase in size of the target gene commensurate with the insertion of an antibiotic resistance cassette (Fig. 1). The antibiotic resistance cassette used as probe hybridised with the target mutant gene only, whereas detectable hybridisation was not observed when the pERFORM suicide plasmid DNA alone was used as a probe.

a

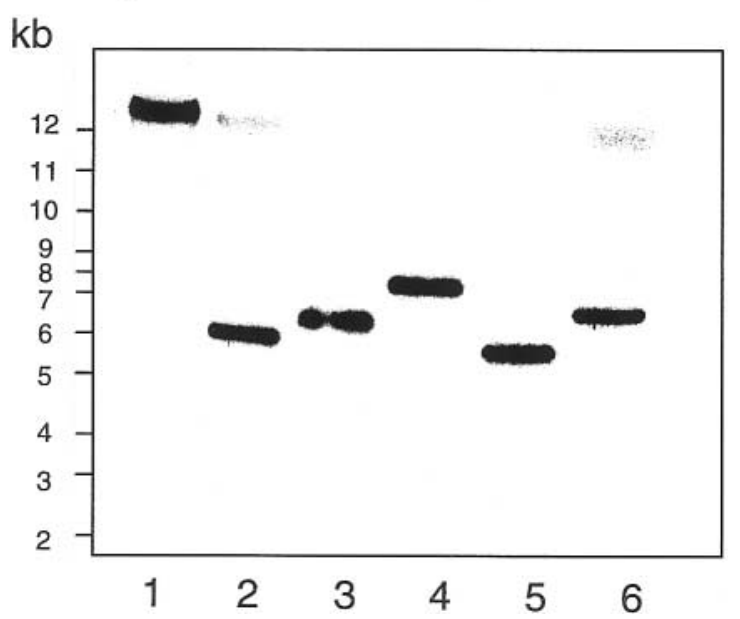

C

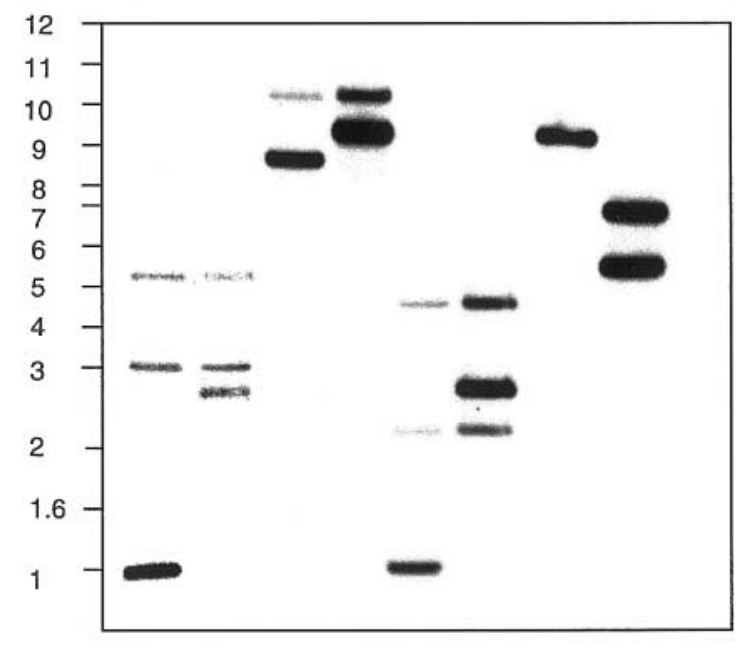

$\begin{array}{llllllll}1 & 2 & 3 & 4 & 5 & 6 & 7 & 8\end{array}$
Strain RML1 (a type-1 non-fimbriate mutant, Fim ${ }^{-}$) failed to agglutinate guinea-pig erythrocytes. Strain RML2 (a curli non-fimbriate mutant, $\mathrm{Crl}^{-}$) did not generate convoluted colonies, failed to bind either Congo red or fibronectin and was negative in an indirect curli ELISA. Strain RML6 (a non-flagellate mutant, $\mathrm{Fla}^{-}$) was non-motile and failed to agglutinate in $\mathrm{H} 9$ antiserum. Multiple-mutant strains were tested similarly and behaved as anticipated. All mutant strains were shown to have the same growth rates in vitro as the wild-type strain when cultured in LB broth (data not shown).

\section{Adherence of non-fimbriate and non-flagellate mutant strains to tissue-culture cells}

Single and multiple isogenic non-fimbriate and nonflagellate mutant strains were compared with the isogenic wild-type strain in HEp-2, HT2916E and HT2919A cell-adhesion assays (Table 6). In tests with HEp-2 cells, mutant strains defective in the elaboration of type-1 fimbriae (strain RML1, Fim ${ }^{-}$; strain RML3, Fim $^{-} \mathrm{Crl}^{-}$; strain RML7, Fim ${ }^{-} \mathrm{Fla}^{-}$; strain RML9,

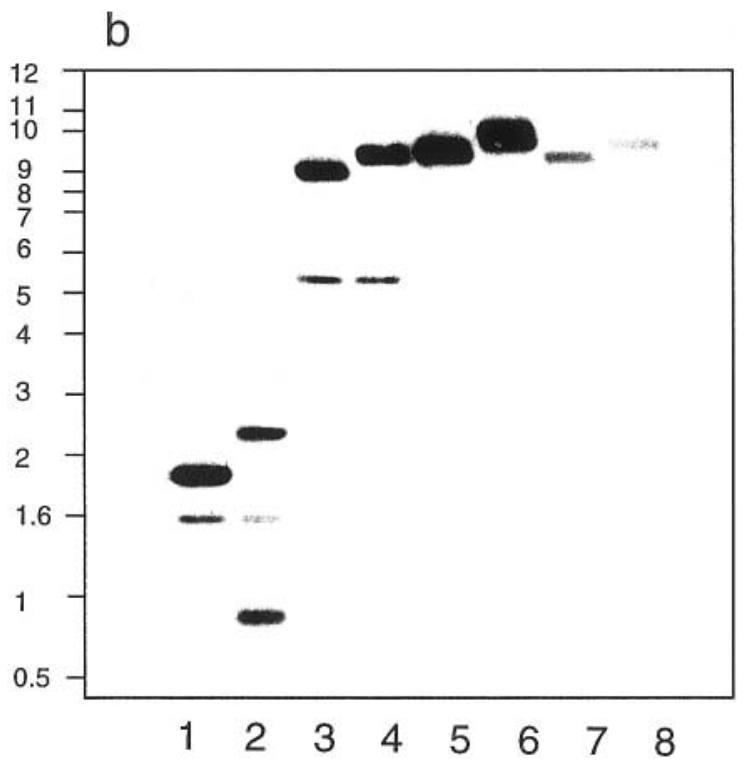

Fig. 1. Southern hybridisation of E. coli O78:K80 strain EC34195 and isogenic derivatives to demonstrate insertional inactivation of target fimbrial and flagellar genes. (a) Lanes 1, 3, 5, wild-type strain and lanes 2, 4, 6, strain RML1 ( fim $\left.C:: \operatorname{kan}^{\mathrm{r}}\right)$; DNA digested to completion with HindIII $(\mathbf{1}, \mathbf{2}), E c o$ RV $(\mathbf{3}, \mathbf{4})$ or $P v u I I(5,6)$ and hybridised against fim $C$. (b) Lanes 1, 3, 5, 7, wild-type strain and lanes $2, \mathbf{4}, \mathbf{6}, \mathbf{8}$, strain RML2 $\left(\operatorname{csg} A:: \operatorname{cam}^{\mathrm{r}}\right)$; DNA digested to completion with $\operatorname{Sca} \mathrm{I}(\mathbf{1}, \mathbf{2})$, Pst I $(\mathbf{3}$, 4), Cla I $(5,6)$ or $\operatorname{SmaI}(7,8)$ and hybridised against $\operatorname{csg} A$. (c) Lanes $\mathbf{1}, \mathbf{3}, \mathbf{5}, \mathbf{7}$, wild-type strain and lanes $\mathbf{2}$, 4, 6, 8 strain RML6 $\left(f i \mathrm{C}:: \operatorname{str}^{\mathrm{r}}\right)$; DNA digested to completion with PstI $(\mathbf{1}, \mathbf{2})$, HindIII $(\mathbf{3}, \mathbf{4})$, HpaI $(\mathbf{5}$, 6) and $B g l \mathrm{I}(7,8)$ and hybridised against $f l \mathrm{C}$. 
Table 6. Adherence of wild-type, single and multiple mutant strains of $E$. coli to different cell lines

\begin{tabular}{|c|c|c|c|c|c|c|c|c|c|c|}
\hline \multirow[b]{2}{*}{ Cluster* } & \multirow[b]{2}{*}{ Strain } & \multicolumn{3}{|c|}{ HEp- $2^{\dagger}$} & \multicolumn{3}{|c|}{ HT2916E ${ }^{\dagger}$} & \multicolumn{3}{|c|}{$\mathrm{HT}^{2919 \mathrm{~A}^{\dagger}}$} \\
\hline & & $\begin{array}{c}\operatorname{Mean}^{\dagger} \\
\log _{10}\end{array}$ & (SEM) & $\begin{array}{l}\text { Significance } \\
(\mathrm{p})^{t}\end{array}$ & $\begin{array}{c}\operatorname{Mean}^{\dagger} \\
\log _{10}\end{array}$ & (SEM) & $\begin{array}{l}\text { Significance } \\
(\mathrm{p})^{*}\end{array}$ & $\begin{array}{c}\operatorname{Mean}^{\dagger} \\
\log _{10}\end{array}$ & (SEM) & $\begin{array}{c}\text { Significance } \\
\text { (p) }\end{array}$ \\
\hline \multirow[t]{4}{*}{ I } & Wild-type & 5.88 & $(0.09)$ & - & 5.93 & $(0.11)$ & - & 5.99 & $(0.13)$ & - \\
\hline & RML1 & 5.26 & $(0.09)$ & $<0.001$ & 4.68 & $(0.13)$ & $<0.001$ & 5.00 & $(0.13)$ & 0.013 \\
\hline & RML2 & 5.91 & $(0.10)$ & 0.823 & 5.74 & $(0.13)$ & 0.273 & 6.00 & $(0.13)$ & 0.976 \\
\hline & RML6 & 5.40 & $(0.56)$ & 0.527 & 4.73 & $(0.13)$ & $<0.001$ & 5.33 & $(0.13)$ & 0.038 \\
\hline \multirow[t]{2}{*}{ II } & Wild-type & 6.01 & $(0.56)$ & - & 5.93 & $(0.11)$ & - & 6.18 & $(0.06)$ & - \\
\hline & RML3 & 5.36 & $(0.11)$ & 0.006 & 4.83 & $(0.18)$ & $<0.001$ & 5.00 & $(0.06)$ & $<0.001$ \\
\hline \multirow[t]{4}{*}{ III } & Wild-type & 6.03 & $(0.17)$ & - & 5.93 & $(0.11)$ & - & 6.13 & $(0.03)$ & - \\
\hline & RML7 & 5.03 & $(0.20)$ & 0.019 & 4.73 & $(0.18)$ & $<0.001$ & 4.94 & $(0.03)$ & $<0.001$ \\
\hline & RML8 & 5.16 & $(0.20)$ & 0.030 & 4.84 & $(0.18)$ & $<0.001$ & 5.94 & $(0.03)$ & 0.011 \\
\hline & RML9 & 5.21 & $(0.20)$ & 0.035 & 4.75 & $(0.18)$ & $<0.001$ & 4.94 & $(0.03)$ & $<0.001$ \\
\hline
\end{tabular}

*For ease of manipulation, and to provide multiple values for wild-type strains for statistical analysis, assays were performed in three clusters (I-III).

${ }^{\dagger}$ Mean bacterial counts obtained after culture of inoculum in $\mathrm{HIB}$ at $37^{\circ} \mathrm{C}$ for $48 \mathrm{~h}$

\$Significance values calculated with reference to wild-type strains (wild-type versus mutant).

$\left.\mathrm{Fim}^{-} \mathrm{Crl}^{-} \mathrm{Fla}^{-}\right)$showed a reduction in adherence of the order of $90 \%(\mathrm{p}<0.001, \mathrm{p}=0.006, \mathrm{p}=0.019$, $\mathrm{p}=0.035$, respectively) when compared with the wildtype strain. The curli non-fimbriate mutant strain RML2 $\left(\mathrm{Crl}^{-}\right)$showed no reduction in adherence and the non-flagellate mutant strain RML6 $\left(\mathrm{Fla}^{-}\right)$showed a reduced adherence of $c$. 50\% compared with the wildtype strain, although this difference was not statistically significant $(\mathrm{p}=0.527)$. It was of interest that the curli non-fimbriate, non-flagellate mutant strain RML8 $\left(\mathrm{Crl}^{-}, \mathrm{Fla}^{-}\right)$was significantly less adherent (c. 90\%) than the wild-type strain $(p=0.030)$.

At least $80 \%$ of the HT2916E cells secreted mucus and the adherence of strain RML6 $\left(\mathrm{Fla}^{-}\right)$to this cell line was reduced by $>90 \%$ compared with the wild-type strain $(p<0.001)$. Other mutant strains, lacking either type-1 fimbriae or flagella, also showed reduced adherence of the order of $90 \%$ when compared with the wild-type strain; again, these findings were statistically significant. Adherence of strain RML2 $\left(\mathrm{Crl}^{-}\right)$was not reduced significantly $(\mathrm{p}=0.273)$.

With the non-mucus-secreting cell line HT2919A, all mutant strains lacking type-1 fimbriae showed reduced adherence (c. 90\%) compared with the wild-type strains and this difference was statistically significant. Strains RML6 $\left(\mathrm{Fla}^{-}\right)$and RML8 $\left(\mathrm{Fla}^{-} \mathrm{Crl}^{-}\right)$both showed c. $40 \%$ reduction in adherence compared with the wild-type strain $(\mathrm{p}=0.038, \mathrm{p}=0.011$, respec- tively) but the curli non-fimbriate mutant, strain RML2 $\left(\mathrm{Crl}^{-}\right)$adhered as well as the wild-type strain.

Invasion of HEp-2 and HT2916E cells by nonfimbriate and non-flagellate mutant strains

Invasion assays were set up for mutant strains RML1 $\left(\mathrm{Fim}^{-}\right)$, RML2 $\left(\mathrm{Crl}^{-}\right)$and RML6 $\left(\mathrm{Fla}^{-}\right)$only in HEp-2 and HT2916E cells (Table 7). With HEp-2 cells, invasion of strain RML1 $\left(\right.$ Fim $\left.^{-}\right)$was reduced to $c$. $0.01-0.05 \%$ of adherent bacteria compared with $0.1 \%$ for the wild-type strain, a significant finding $(\mathrm{p}=0.027)$. The reduction in invasion by strains RML2 $\left(\mathrm{Crl}^{-}\right)$and RML6 (Fla $\left.{ }^{-}\right)$was not statistically significant $(\mathrm{p}=0.285, \mathrm{p}=0.230$, respectively). About $0.005-0.01 \%$ of adherent wild-type bacteria invaded HT2916E cells, and this level of invasion was less than that for similar experiments with HEp-2 cells. Strains RML1 $\left(\mathrm{Fim}^{-}\right)$, RML2 $\left(\mathrm{Crl}^{-}\right)$and RML6 $\left(\mathrm{Fla}^{-}\right)$were less invasive than the wild-type strain $(\mathrm{p}<0.001$, $\mathrm{p}=0.010, \mathrm{p}<0.001$, respectively), although the extent of invasion in these assays was directly proportional to the extent of adhesion.

\section{Development of chick tracheal and gut explant adhesion models}

Bacterial growth was not detectable when tracheal and proximal gut samples (before incubation with test bacteria) were homogenised and plated on LB agar

Table 7. Invasion* of HEp-2 and HT2916E cells by wild-type and single mutant strains of E. coli

\begin{tabular}{|c|c|c|c|c|c|c|}
\hline \multirow[b]{2}{*}{ Strain } & \multicolumn{3}{|c|}{ HEp-2 } & \multicolumn{3}{|c|}{ HT2916E } \\
\hline & Mean $\log _{10}$ & (SEM) & Significance $(p)^{\dagger}$ & Mean $\log _{10}$ & (SEM) & Significance $(p)^{\dagger}$ \\
\hline Wild-type & 3.27 & $(0.06)$ & - & 2.91 & $(0.03)$ & - \\
\hline RML1 & 3.03 & $(0.06)$ & 0.027 & 2.25 & $(0.03)$ & $<0.001$ \\
\hline RML2 & 3.17 & $(0.06)$ & 0.285 & 2.67 & $(0.03)$ & 0.010 \\
\hline Wild-type & 2.69 & $(0.16)$ & - & 2.91 & $(0.03)$ & - \\
\hline RML6 & 2.29 & $(0.16)$ & 0.230 & 2.03 & $(0.03)$ & $<0.001$ \\
\hline
\end{tabular}

* Mean bacterial counts obtained after culture of inoculum in $\mathrm{HIB}$ at $37^{\circ} \mathrm{C}$ for $48 \mathrm{~h}$.

${ }^{\dagger}$ Significance values calculated with reference to wild-type strains (wild-type versus mutant). 
with aerobic incubation overnight at $37^{\circ} \mathrm{C}$. Tissues showed signs of disaggregation after incubation for $4 \mathrm{~h}$, and, for convenience, sampling was done $3 \mathrm{~h}$ after inoculation. After exposure to bacteria, tissues were fixed and examined by scanning electron microscopy (Fig. 2a and b). Counts of bacteria from 10 randomly selected fields per tissue surface showed preferential adherence to the ciliated epithelial rather than the serous surface (ratio 80:1). Furthermore, bacteria adhered singly and not as aggregates or clumps. Significant differences in adherence were not seen between different areas of the gut or trachea when $E$. coli strain EC34195 was incubated with similarly sized sections of tissues of proximal, mid and distal trachea, proximal, mild and distal gut, caecum or rectum.

\section{Adhesion of non-fimbriate and non-flagellate mutant strains to explant tissue}

The adherence to tracheal explant tissue (Table 8) of mutant strains defective in the elaboration of type-1 fimbriae (strain RML1, Fim ${ }^{-}$; strain RML3, Fim ${ }^{-}$ $\mathrm{Crl}^{-}$; strain RML7, Fim ${ }^{-} \mathrm{Fla}^{-}$; strain RML9, Fim ${ }^{-}$ $\mathrm{Crl}^{-} \mathrm{Fla}^{-}$) was reduced by $c$. $60-90 \%$ compared with that of the wild-type strain; these differences were significant $(\mathrm{p}<0.001, \mathrm{p}=0.016, \mathrm{p}=0.036, \mathrm{p}=$ 0.042 , respectively). There was no significant reduction in adherence for either the curli non-fimbriate strain RML2 $\left(\mathrm{Crl}^{-}\right)$or the non-flagellate strain RML6 $\left(\mathrm{Fla}^{-}\right)$, although the adherence of strain RML8 $\left(\mathrm{Fla}^{-} \mathrm{Crl}^{-}\right)$ was reduced by $c .75 \%$ compared with that of the wildtype strain, a finding which was significant $(\mathrm{p}=0.036)$.

The adherence to gut explant tissue (Table 8) of strains RML1 $\left(\mathrm{Fim}^{-}\right)$and RML2 $\left(\mathrm{Crl}^{-}\right)$was reduced by $c$. $90 \%$ and $80 \%$, respectively, compared with that of the wild-type strain ( $p=0.002, p=0.005$, respectively). It was surprising that the adherence of strains RML3, defective in the elaboration of both type- 1 and curli fimbriae, was reduced by c. $70 \%$ compared with that of the wild-type strain, a reduction that was not statistically significant $(p=0.496)$. In this model, the role of flagella was found to be equivocal with strains RML6 (Fla $\left.{ }^{-}\right)$, RML8 $\left(\mathrm{Crl}^{-}, \mathrm{Fla}^{-}\right)$and RML9 (Fim ${ }^{-}$, $\mathrm{Crl}^{-}, \mathrm{Fla}^{-}$) showing only marginally less adherence than the wild-type strain $(\mathrm{p}=0.086, \mathrm{p}=0.068$, $\mathrm{p}=0.123$, respectively), although adherence of strain RML7 $\left(\mathrm{Fim}^{-} \mathrm{Fla}^{-}\right.$) was reduced by $90 \%$ compared with that of the wild-type strain $(\mathrm{p}=0.016)$.

After incubation with bacteria for $3 \mathrm{~h}$ both gut and tracheal explant tissues were shown by electron microscopy to have lost much of the mucus. That may have influenced the findings.

\section{Influence of culture of inoculum on curli fimbriae-mediated adherence to tissue culture}

Curli fimbriae were not detectable by electron microscopy on wild-type bacteria grown in HIB at $37^{\circ} \mathrm{C}$ for
$48 \mathrm{~h}$, although evidence was presented that curli nonfimbriate mutant strains grown under these conditions were less adherent to gut explants than the wild-type strain. When inocula were prepared by growth in CFA broth at $25^{\circ} \mathrm{C}$ for $72 \mathrm{~h}$ without shaking, conditions known to support expression of curli but not type-1 fimbriae $[30,38]$, adherence of strain $\mathrm{RML} 2\left(\mathrm{Crl}^{-}\right)$to both mucus-secreting and mucus-non-secreting cell lines was reduced by $>80 \%$ compared with that of the wild-type strain $(p=0.003$ and $p=0.026$, respectively). Similar reductions were observed for all other mutant strains prepared under these conditions (Table 9) and of particular note was the reduction in adherence to the mucus cells of $>90 \%$ for mutant strains defective in the elaboration of flagella $(\mathrm{p}<0.001)$.

\section{Discussion}

Non-fimbriate and non-flagellate mutant strains were constructed in E. coli O78:K80 strain EC34195 by allelic exchange and evidence was gained that these strains possessed an antibiotic resistance cassette in the targeted genes and possessed the desired phenotypic changes. Allelic exchange is an established technique and it was considered unlikely that other, less overt phenotypic changes might have resulted from the mutagenesis strategy used. Considerable phenotypic diversity was shown by the small panel of avian, colibacillosis-causing isolates of O78:K80 examined and an additional question arose as to whether strain EC34195 was typical of avian colibacillosis strains. P fimbriae are elaborated by many avian isolates of $E$. coli $[17,43]$, but the isolates tested in this study did not elaborate mannose-resistant haemagglutination and did not possess pap genes as determined by PCR. Electron microscopy confirmed the absence of $\mathrm{P}$ fimbriae or any other, hitherto undescribed surface elaborated structures and so it was reasonable to assume that differences observed in adherence and invasion assays were likely to result from the phenotypic outcome of each mutation.

All adhesion assays indicated that type-1 fimbriae were of particular significance in mediating adhesion of $E$. coli O78:K80 to epithelial cells. This finding was consistent with studies with $E$. coli of many other serotypes including other avian colibacillosis serotypes such as $\mathrm{O} 1: \mathrm{K} 1$ and $\mathrm{O} 2: \mathrm{K} 1[10,15]$. Again, evidence was presented that E. coli O78:K80 strain EC34195 adhered to tracheal explants more effectively than to gut explants. This may reflect the density of receptors - largely type-1 fimbrial adhesin, mannose-bearing glycoproteins $[44,45]$ - or innate tropism for tracheal tissues which may also relate to the specific adhesinreceptor interactions.

Flagella have been cited as mediating penetration of mucus before epithelial adherence mediated by type-1, 

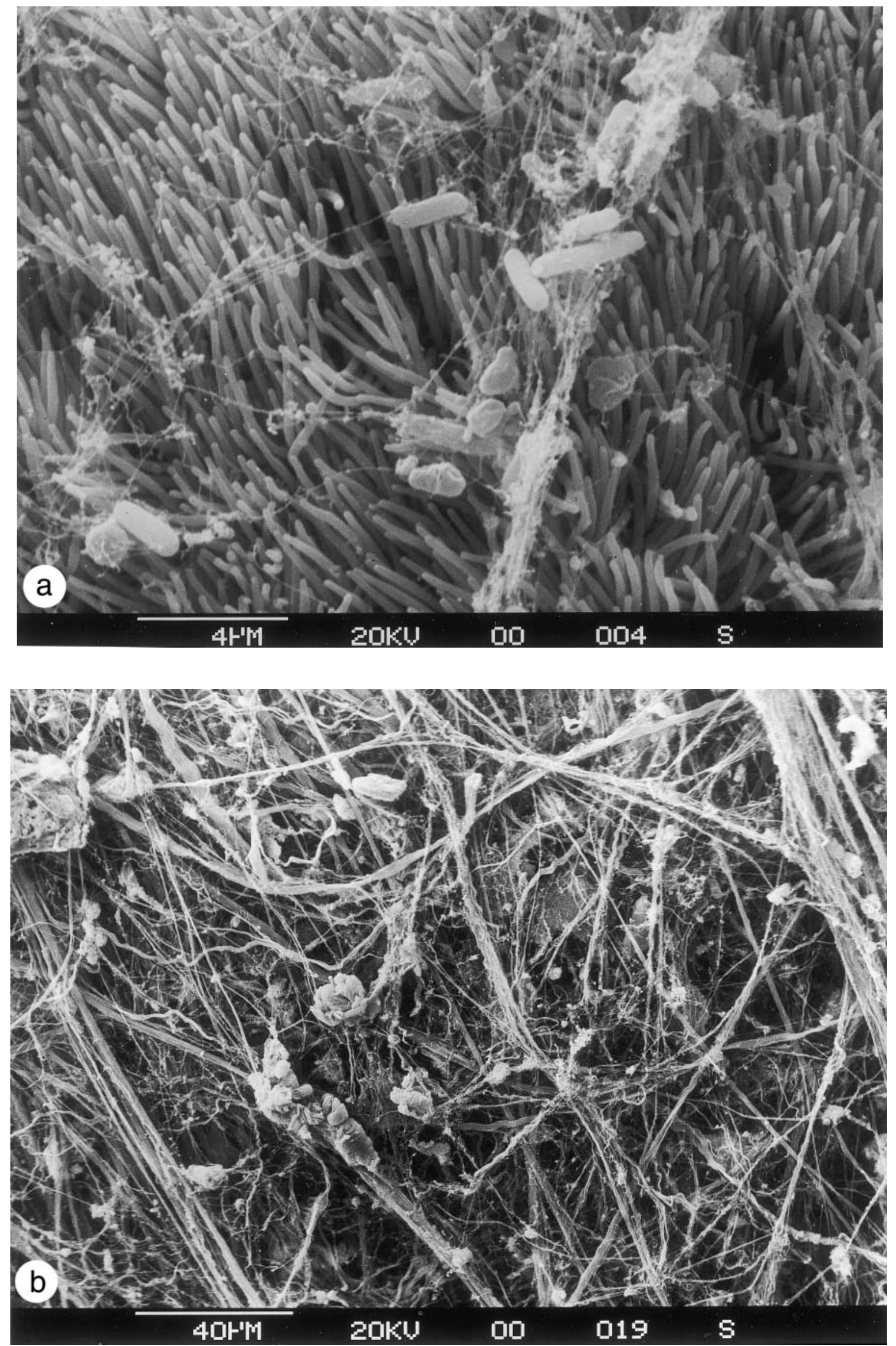

Fig. 2. (a) Scanning electron micrograph of tracheal tissue explant showing ciliated luminal surface after exposure to bacteria of E. coli O78:K80 strain EC34195 for $3 \mathrm{~h}$. Magnification shown by white bar, marker. (b) Scanning electron micrograph of tracheal tissue explant showing fibroblastic surface after exposure to bacteria of E. coli O78:K80 strain EC34195 for $3 \mathrm{~h}$. Magnification shown by white bar, marker. 
Table 8. Adherence of wild-type, single and multiple mutant strains of E. coli to tracheal and gut explant tissue

\begin{tabular}{|c|c|c|c|c|c|c|}
\hline \multirow[b]{2}{*}{ Strain } & \multicolumn{3}{|c|}{ Tracheal tissue } & \multicolumn{3}{|c|}{ Gut tissue } \\
\hline & Mean* $\log _{10}$ & (SEM) & Significance $(p)^{\dagger}$ & Mean* $\log _{10}$ & (SEM) & Significance $(p)^{\dagger}$ \\
\hline Wild-type & 5.96 & $(0.10)$ & - & 4.93 & $(0.08)$ & - \\
\hline RML1 & 5.10 & $(0.10)$ & $<0.001$ & 3.89 & $(0.08)$ & 0.002 \\
\hline Wild-type & 6.08 & $(0.07)$ & - & 4.93 & $(0.08)$ & - \\
\hline RML2 & 6.15 & $(0.07)$ & 0.526 & 4.11 & $(0.08)$ & 0.005 \\
\hline Wild-type & 5.93 & $(0.01)$ & - & 4.23 & $(0.33)$ & - \\
\hline RML3 & 5.44 & $(0.01)$ & 0.016 & 3.85 & $(0.33)$ & 0.469 \\
\hline Wild-type & 5.54 & $(0.13)$ & - & 4.93 & $(0.08)$ & - \\
\hline RML6 & 5.50 & $(0.13)$ & 0.845 & 4.66 & $(0.08)$ & 0.086 \\
\hline Wild-type & 5.10 & $(0.27)$ & - & 5.11 & $(0.19)$ & - \\
\hline RML7 & 4.36 & $(0.27)$ & 0.302 & 4.09 & $(0.19)$ & 0.160 \\
\hline Wild-type & 5.08 & $(0.03)$ & - & 4.83 & $(0.06)$ & - \\
\hline RML8 & 4.41 & $(0.03)$ & 0.036 & 4.03 & $(0.06)$ & 0.068 \\
\hline Wild-type & 5.33 & $(0.04)$ & - & 4.91 & $(0.09)$ & - \\
\hline RML9 & 4.47 & $(0.04)$ & 0.042 & 4.24 & $(0.09)$ & 0.123 \\
\hline
\end{tabular}

* Mean counts of adherent bacteria after culture of inoculum in $\mathrm{HIB}$ at $37^{\circ} \mathrm{C}$ for $48 \mathrm{~h}$.

${ }^{\dagger}$ Significance values calculated with reference to wild-type strains (wild-type versus mutant).

Table 9. Adherence of wild-type and single mutant strains of E. coli to different cell lines

\begin{tabular}{|c|c|c|c|c|c|c|c|c|c|}
\hline \multirow[b]{2}{*}{ Strain } & \multicolumn{3}{|c|}{ HEp-2* } & \multicolumn{3}{|c|}{ HT2916E* } & \multicolumn{3}{|c|}{ HT2919A* } \\
\hline & $\begin{array}{l}\text { Mean } \\
\log _{10}\end{array}$ & (SEM) & $\begin{array}{c}\text { Significance } \\
(p)^{\dagger}\end{array}$ & $\begin{array}{l}\text { Mean } \\
\log _{10}\end{array}$ & (SEM) & $\begin{array}{c}\text { Significance } \\
(\mathrm{p})^{\dagger}\end{array}$ & $\begin{array}{l}\text { Mean } \\
\log _{10}\end{array}$ & (SEM) & $\begin{array}{c}\text { Significance } \\
(\mathrm{p})^{\dagger}\end{array}$ \\
\hline Wild-type & 6.71 & $(0.046)$ & - & 6.64 & $(0.061)$ & - & 6.47 & $(0.117)$ & - \\
\hline RML1 & 5.97 & $(0.046)$ & 0.001 & 5.96 & $(0.061)$ & 0.004 & 5.71 & $(0.117)$ & 0.020 \\
\hline RML2 & 6.41 & $(0.046)$ & 0.020 & 5.87 & $(0.061)$ & 0.003 & 5.78 & $(0.117)$ & 0.026 \\
\hline RML6 & 6.52 & $(0.046)$ & 0.213 & 5.45 & $(0.061)$ & $<0.001$ & 5.71 & $(0.117)$ & 0.019 \\
\hline
\end{tabular}

${ }^{*}$ Mean bacterial counts after culture of inoculum in CFA broth at $25^{\circ} \mathrm{C}$ for $72 \mathrm{~h}$.

${ }^{\dagger}$ Significance values: see footnotes to Table 8 .

and other, fimbrial and non-fimbrial surface antigens [46]. The data generated in this work support that concept in that non-flagellate mutant strains adhered less well to the mucus secreting cell line HT2916E than did the wild-type strain. It was of interest that non-flagellate mutant strains adhered less well to the non-secreting cell line HT2919A, indicating that factors other than flagella and mucus was important in adherence to the HT2916-type cell lines. Whether the use of tissue explants gave a clearer understanding of the role of flagella is also open to debate, especially as non-flagellate mutant strains were not significantly less adherent than the wild-type strain. Gut and tracheal explant tissues from day-old chicks may lack fimbrial adhesin receptors because of immaturity [47], and that may have influenced results. Electron microscopic analysis of tissues after incubation with bacteria indicated that mucus was absent and it is probable that mucus was lost by the sheer forces associated with the agitation used during incubation. In addition, that agitation may have provided sufficient contact between bacteria and tissue such that any chemotactic role associated with adherence was not apparent.

Curli non-fimbriate mutant strains grown in HIB at $37^{\circ} \mathrm{C}$ for $48 \mathrm{~h}$ showed only a marginal and statistically equivocal reduction in adherence to explants, but no reduction of adherence to tissue culture cells in vitro.
When the bacterial inoculum was prepared in CFA broth at $25^{\circ} \mathrm{C}$ for $72 \mathrm{~h}$, conditions which induce the production of curli, but not type-1, fimbriae [38, 48], differences in adherence between mutant and wild-type strains were accentuated and were statistically significant. It was of interest that curli fimbriae were not seen by electron microscopy on HIB-grown bacteria, although differences in adherence between curliate and non-curliate derivatives were observed in gut explant assays. Thus, it is possible that either sufficient curli fimbriae were elaborated in HIB to enable observation of differences or contact with explants stimulated their elaboration. Alternatively, other adhesins may have been elaborated under these conditions. Curli fimbriae mediate aggregation of curliate bacterial cells $[49,50]$, but in this study cell clumping at the epithelial cell surface was not observed by scanning electron microscopy. It was probable that differences in bacterial counts reflected actual adherence values not apparent reductions due to clumping, especially as Triton, which disaggregates bacterial clumps, was a component of the diluent used for the enumeration of adherent bacteria. Bacterial cultural and tissue-culture assay conditions influenced bacterium-host cell interactions, findings in common with those of Duguid and Gillies [51], who showed that anaerobiosis induced fimbriation. Again, Ernst et al. [52] showed that anaerobiosis enhanced invasion. A comprehensive 
comparable study of adherence to a number of cells and tissues has been presented and has indicated that a role in adherence in vitro is associated with each of the structures investigated: i.e., type-1 fimbriae, curli fimbriae and flagella.

We gratefully acknowledge the help of A. R. Sayers with statistical analyses, A. Long with histology and T. Lesuffleur and C. L. Laboisse for supplying the HT-29 cell lines. R. M. La R. was supported by the British Egg Marketing Board (BEMB) Research and Education Trust and was co-sponsored by Hoechst Roussel Vet (Ltd). A.R.S., A.L., W.A.C. and M.J.W. were supported by the Ministry of Agriculture Fisheries and Food (MAFF) GB.

\section{References}

1. Arp LH, Jensen AE. Piliation, hemagglutination, motility, and generation time of Escherichia coli that are virulent or avirulent for turkeys. Avian Dis 1979; 24: 153-161.

2. Filali E, Bell JG, el Houadfi M, Huggins MB, Cook JK. Antibiotic resistance of Escherichia coli strains isolated from chickens with colisepticaemia in Morocco. Comp Immunol Microbiol Infect Dis 1998; 11: 121-124.

3. Marc D, Arne P, Bree A, Dho-Moulin M. Colonization ability and pathogenic properties of a fim-mutant of an avian strain of Escherichia coli. Res Microbiol 1998; 149: 473-485.

4. Gross WB. The development of air sac disease. Avian Dis 1961; 5: 431-439.

5. Gross WB. Colibacillosis. In: Calnek BW, Beard CW, Reid WM, Yoder HW (eds) 9th edn. Iowa, Wolfe Publishing Ltd. 1991: $138-144$

6. Allan BJ, van den Hurk JV, Potter AA. Characterization of Escherichia coli isolated from cases of avian colibacillosis. Can J Veet Res 1993; 57: 146-151.

7. Amara A, El Had S, Jirrari T, Bouzoubaa K. The lethality, hemagglutination and adhesion of Escherichia coli (serotype O1) isolated in Morocco from chickens with colibacillosis. Avian Dis 1996; 40: 540-545.

8. Mims CA, Dimmock NJ, Nash A, Stephen J. Mims' Pathogenesis of infectious disease, 4th edn. London, Academic Press. 1995.

9. Smyth CJ, Marron M, Smith SGJ. Fimbriae of Escherichia coli. In: Gyles CL (ed) Escherichia coli in domestic animals and humans. CAB International. 1994: 399-435.

10. Dho M, Lafont JP. Adhesive properties and iron uptake ability in Escherichia coli lethal and nonlethal for chicks. Avian Dis 1984; 28: 1016-1025.

11. Dozois CM, Chanteloup N, Dho-Moulin M, Bree A, Desautels C, Fairbrother JM. Bacterial colonization and in vivo expression of F1 (type 1) fimbrial antigens in chickens experimentally infected with pathogenic Escherichia coli. Avian Dis 1994; 38: 231-239.

12. Dozois CM, Fairbrother JM, Harel J, Bossé M. pap- and pilrelated DNA sequences and other virulence determinants associated with Escherichia coli isolated from septicemic chickens and turkeys. Infect Immun 1992; 60: 2648-2656.

13. Naveh MW, Zusman T, Skutelsky E, Ron EZ. Adherence pili in avian strains of Escherichia coli: effect on pathogenicity. Avian Dis 1984; 28: 651-661.

14. Viddotto MC, Navarro HR, Gaziri LC. Adherence pili of pathogenic strains of avian Escherichia coli. Vet Microbiol 1997, 59: 79-87.

15. Gyimah JE, Panigrahy B. Adhesin-receptor interactions mediating the attachment of pathogenic Escherichia coli to chicken tracheal epithelium. Avian Dis 1988; 32: 74-78.

16. Krogfelt KA. Bacterial adhesion: genetics, biogenesis and role in pathogenesis of fimbrial adhesins of Escherichia coli. Rev Infect Dis 1991; 13: 721-735.

17. Pourbakhsh SA, Dho-Moulin M, Brée A, Desautels C, Martineau-Doize B, Fairbrother JM. Localization of the in vivo expression of $\mathrm{P}$ and $\mathrm{F} 1$ fimbriae in chickens experimentally inoculated with pathogenic Escherichia coli. Microb Pathog 1997; 22: 331-341.

18. Arnqvist A, Olsén A, Pfeifer J, Russell DG, Normark S. The Crl protein activates cryptic genes for curli formation and fibronectin binding in Escherichia coli HB101. Mol Microbiol
1992; 6: 2443-2452.

19. Hammar M, Arnqvist A, Bian Z, Olsen A, Normark S. Expression of two csg operons is required for the production of fibronectin and Congo red-binding curli polymers in Escherichia coli K-12. Mol Biol 1995; 18: 661-670.

20. Olsén A, Jonsson A, Normark S. Fibronectin binding mediated by a novel class of surface organelles on Escherchia coli. Nature 1989; 338: 652-655.

21. Olsen A, Arnqvist A, Hammer M, Sukupolvi S, Normark S The RpoS sigma factor relieves H-NS-mediated transcriptional repression of $\operatorname{csg} \mathrm{A}$, the subunit gene of fibronectin binding curli in E. coli. Mol Microbiol 1993; 7: 523-536.

22. Sjöbring U, Pohl G, Olsén A. Plasminogen, absorbed Escherichia coli expressing curli or by Salmonella enteritidis expressing thin aggregative fimbriae, can be activated by simultaneously captured tissue-type plasminogen activator (tPA). Mol Microbiol 1994; 14: 443-452.

23. Dho M, Lafont JP. Escherichia coli colonization of the trachea in poultry: comparison of virulent and avirulent strains in gnotoxenic chickens. Avian Dis 1982; 26: 787-797.

24. Arp LH, Brooks EE. An in vivo model for the study of Bordetella avium adherence to tracheal mucosa in turkeys. Am $J$ Vet Res 1986; 47: 2614-1617.

25. Kang G, Mathan MM, Mathan VI. Evaluation of a simplified HEp-2 cell adherence assay for Escherichia coli isolated from South Indian children with acute diarrhea and controls. J Clin Microbiol 1995; 33: 2204-2205.

26. Hancox LS, Yeh KS, Clegg S. Construction and characterization of type 1 non-fimbriate and non-adhesive mutants of Salmonella typhimurium. FEMS Immunol Med Microbiol 1997; 19: 289-296.

27. Mathewson JJ, Salameh BM, Dupont LH et al. HEp-2 celladherent Escherichia coli and intestinal secretory immune response to human immunodeficiency virus (HIV) in outpatients with HIV-associated diarrhea. Clin Diagn Lab Immunol 1998; 5: 87-90.

28. Chart H, Spencer J, Smith HR, Rowe B. Magnesium ions are required for HEp-2 cell adhesion by enteroaggregative strains of Escherichia coli $\mathrm{O} 126: \mathrm{H} 27$ and O44:H118. FEMS Microbiol Lett 1997; 148: 49-52.

29. Polotsky Y, Nataro JP, Kotler D, Barrett TJ, Orenstein JM. HEp-2 cell adherence patterns, serotyping and DNA analysis of Escherichia coli isolates from eight patients with AIDS and chronic diarrhea. J Clin Microbiol 1997; 35: 1951-1958.

30. Alexeyev MF, Shokolenko IN, Croughan TP. Improved antibiotic-resistance gene cassettes and omega elements for Escherichia coli vector construction and in vitro deletion/insertion mutagenesis. Gene 1995; 160: 63-67.

31. Penfold RJ, Pemberton JM. An improved suicide vector for construction of chromosomal insertion mutations in bacteria. Gene 1992; 118: 145-146.

32. Allen-Vercoe E, Dibb-Fuller M, Thorns CJ, Woodward MJ SEF17 fimbriae are essential for the convoluted colonial morphology of Salmonella enteritidis. FEMS Microbiol Lett 1997; 153: 33-42.

33. Allen-Vercoe E, Woodward MJ. Adherence of Salmonella enterica serovar Enteritidis to chick gut explant; the role of flagella but not fimbriae. J Med Microbiol 1999; 48: 1-10.

34. Simon R, Priefer U, Puhler A. A broad host-range mobilisation system for in vivo genetic engineering: transposon mutagenesis in Gram-negative bacteria. Biotech 1983; 1: 784-791.

35. La Ragione RM, Collighan RJ, Woodward MJ. Non-curliation of Escherchia coli O78:K80 isolates associated with IS1 in $\operatorname{csg} B$ and reduced persistence in poultry infection. FEMS Microbiol Lett 1999; 175: 247-254.

36. Allen-Vercoe E, Woodward MJ. Construction of improved sucide vectors and their use in site directed mutagenesis of fimbrial genes of Salmonella enteritidis. Salmonella and Salmonellosis Proceedings, Ploufragan, 1997.

37. Dibb-Fuller M, Allen-Vercoe E, Thorns CJ, Woodward MJ. Fimbriae- and flagella-mediated associated with and invasion of cultured epithelial cells by Salmonella enteritidis. Microbiology 1999; 145: 1023-1031.

38. Dibb-Fuller M, Allen-Vercoe E, Woodward MJ, Thorns CJ. Expression of SEF17 fimbriae by Salmonella enteritidis. Lett Appl Microbiol 1997; 25: 447-452.

39. Maniatis T, Fritsch EF, Sambrook J. Molecular cloning: a laboratory manual. Cold Spring Harbor, NY, Cold Spring Harbor Laboratory. 1982. 
40. Anonymous. Manual of histologic and special staining technics. Washington, DC, Armed Forces Institute of Pathology. 1957.

41. Lesuffleur T, Roche F, Hill AS et al. Characterization of a mucin cDNA clone isolated from HT-29 mucus-secreting cells. $J$ Biol Chem 1995; 270: 13665-13673.

42. Augeron C, Laboisse CL. Emergence of permanently differentiated cell clones in a human colonic cancer cell line in culture after treatment with sodium butyrate. Cancer Res 1984; 44: 3961-3969.

43. van den Bosch JF, Hendriks JHIM, Gladigau I, Willems HMC, Storm PK, de Graaf FK. Identification of F11 fimbriae on chicken Escherichia coli strains. Infect Immun 1993; 61: 800-806.

44. Duguid JP, Old DC. Adhesive properties of Enterobacteriaceae. In: Beachey EH (ed) Bacterial adherence, receptors and recognition, series B, vol 6. London, Chapman and Hall. 1980: $185-217$.

45. Salit IE, Gotschlich EC. Type 1 Escherichia coli pili: characterization of binding to monkey kidney cells. J Exp Med 1977; 146: 1182-1194.

46. Smyth CJ. Flagella: their role in virulence. In: Owen P, Foster TJ (eds) Immunochemical and molecular genetic analysis of bacterial pathogens. Amsterdam, Elsevier. 1988: 3-11.

47. Jeurissen SHM, Janse EM, Koch G, De Boer GF. Postnatal development of mucosa-associated lymphoid tissues in chickens. Cell Tissue Res 1989; 258: 119-124.

48. Walker SL, Sojka M, Dibb-Fuller M, Woodward MJ. Effect of $\mathrm{pH}$, temperature and surface contact on the elaboration of fimbriae and flagella by Salmonella serotype Enteritidis. $J$ Med Microbiol 1999; 48: 253-261.

49. Collinson SK, Doig PC, Dorman JL, Clouthier S, Trust TJ, Kay WW. Thin, aggregative fimbriae mediate binding of Salmonella enteritidis to fibronectin. J Bacteriol 1993; 175: $12-18$.

50. Collinson SK, Emödy L, Müller K-H, Trust TJ, Kay WW. Purification and characterization of thin, aggregative fimbriae from Salmonella enteritidis. J Bacteriol 1991; 173: 47734781 .

51. Duguid JP, Gillies RR. Fimbriae and adhesive properties in dysentery bacilli. J Pathol Bacteriol 1957; 74: 397-411.

52. Ernst RK, Dombroski DM, Merrick JM. Anaerobiosis, Type 1 fimbriae, and growth phase are factors that affect invasion of HEp-2 cells by Salmonella typhimurium. Infect Immun 1990; 58: $2014-2016$. 